\title{
Perspective from Government Officer: Ecotourism for City Branding of Pinrang Regency, South Sulawesi
}

\section{Eli Jamilah Mihardja ${ }^{1}$, B. P. Kusumo Bintoro ${ }^{2}$, D.M. Putri ${ }^{3}$, T. Widiastuti ${ }^{4}$, P.M. Agustini ${ }^{5}$ and F. Adriati ${ }^{6}$}

\author{
${ }^{1}$ Universitas Bakrie Jakarta, Indonesia \\ ${ }^{2}$ Universitas Bakrie Jakarta, Indonesia \\ ${ }^{3}$ Universitas Bakrie Jakarta, Indonesia \\ ${ }^{4}$ Universitas Bakrie Jakarta, Indonesia \\ ${ }^{5}$ Universitas Bakrie Jakarta, Indonesia \\ ${ }^{6}$ Universitas Bakrie Jakarta, Indonesia
}

\begin{abstract}
Brand determines the success of a company, as well as branding a city. In the era of regional autonomy and transparency of information, city branding has a major role as a strategy to gain a reputation and a strong positioning in the face of competition with other cities. Therefore, this study aims to identify and mapping the potential areas to be formed as city branding, in particular by exploiting the potential of ecotourism in Pinrang, especially from the perspective of local government. Keywords: City Branding, Pinrang, ecotourism
\end{abstract}

\section{Introduction}

This paper is a part of research funded by Ministry of Research and Higher Education in PDPT schema for 2018. According to the development of the research program within the Bakrie University is formulated into the basic research program, namely "Research for sustainable development based on the spirit of techno-preneurship". This basic program is very suitable to be applied to the idea of using ecotourism potential as a city branding. Ecotourism will ensure sustainable development. Therefore, it is necessary to conduct research related to the development of models, systems and governance of ecotourism as an integrated city branding strategy so that sustainable development can be realized. This research focuses on the topic mainly on the identification of ecotourism potential as a city branding of Pinrang Regency and also the preparation of city branding strategies

A Glimpse of Studies on City Branding and Ecotourism. Ady (2015) points out that ecotourism can be an effective sales strategy on a farming area. The results of Eli Jamilah et al (2016) research revealed that there were opportunities to exploit the potential of ecotourism as a city branding strategy for Pinrang district, South Sulawesi. This is supported by the potential of the landscape of Pinrang district, the facilities and infrastructure of the local government, and the culture of the community. Citizens of Pinrang Regency are part of the world diaspora who return to 'go home' to popularize ecotourism locations through social media. The narcissistic culture of citizens through social media, whether they realize it or not, can be a capital for the popularity of the ecotourism potential. However, this potential cannot be utilized maximally precisely because of lack of awareness and the need to establish city branding. This situation can be caused by lack of adequate knowledge and there are no experts who can help formulate city branding as programmed by the central government through the Ministry of Tourism.

City branding is adapted from corporate branding, then city branding is understood as a network of association or perception in the minds of consumers (tourists, investors, etc.), so that city branding can be defined as a network of associations in the minds of consumers, based on the visual, verbal and behavioral expression of a place, which is realized through the goals, communication, values, and general culture of stakeholders, as well as the design of the place / city as a whole (Zenker 2011; Yananda \& Salamah, 2014: 62). City branding strategy is certainly not only sourced from ecotourism potential, but ecotourism has various advantages regarding sustainable development. This is in line 
with the vision and mission of the University. This research will also show the integration of the role of stakeholders, regional potential and academic expertise can be pioneered towards maximizing the use of ecotourism and the preparation of city branding so as to produce a clearer regional identity and policy direction.

Ecotourism is then a combination of various interests that grow from environmental, economic and social concerns. Ecotourism cannot be separated from conservation. Therefore, ecotourism is referred to as a form of responsible tourism travel (Fandeli, 2000). Ecotourism has the advantage of sustainability and nature conservation. Socially, ecotourism increases income, expenditure and production assets (Tafalas, 2010). Therefore, the development of ecotourism should be used as material for the preparation of city branding.

\section{Research Methodology}

We used mixed-method; consist of quantitative survey with questionnaire and qualitative methods with focus group discussion and in-depth interviews, as detail follows

Table 1. Research methods

\begin{tabular}{|c|c|c|c|}
\hline INPUT & PROCESS & OUTPUT & OUTCOMES \\
\hline $\begin{array}{l}\text { Literature } \\
\text { study and } \\
\text { variable } \\
\text { assessment }\end{array}$ & $\begin{array}{l}\text { Learning previous } \\
\text { study about city } \\
\text { branding and } \\
\text { ecotourism }\end{array}$ & $\begin{array}{l}\text { Concept and } \\
\text { operational } \\
\text { concept }\end{array}$ & $\begin{array}{l}\text { 1. a measuring instrument of each research } \\
\text { concept and questionnaire for the formulation } \\
\text { of a city branding strategy by utilizing the } \\
\text { potential of ecotourism } \\
\text { 2. discussion guidelines of each variable } \\
\text { under study to conduct depth interviews }\end{array}$ \\
\hline $\begin{array}{l}\text { Data } \\
\text { Gathering }\end{array}$ & $\begin{array}{l}\text { 1. Pre-research } \\
\text { observation } \\
\text { survey. } \\
\text { 2. Documents, } \\
\text { procedures and } \\
\text { data available } \\
\text { from benchmark } \\
\text { companies } \\
\text { 3. Depth } \\
\text { interview } \\
\text { 4. FGD }\end{array}$ & Data & $\begin{array}{l}\text { Gathering of representatives of each data to } \\
\text { date to support the engineering and data } \\
\text { processing }\end{array}$ \\
\hline $\begin{array}{l}\text { Data } \\
\text { Analysis }\end{array}$ & $\begin{array}{l}\text { Organizing data } \\
\text { through verbatim, } \\
\text { coding, and } \\
\text { decoding. }\end{array}$ & $\begin{array}{l}\text { Data } \\
\text { Organized. }\end{array}$ & $\begin{array}{l}\text { Draft drafted integration strategy model for } \\
\text { preparing city branding strategies }\end{array}$ \\
\hline
\end{tabular}

For the purpose of mapping, we use in-depth interview with source from Dinas Pariwisata, Pemuda dan Olahraga, Dinas Informatika dan Komunikasi, and Badan Pembangunan Daerah Kabupaten Pinrang. (Department of Tourism, Youth and Sports, Department of Informatics and Communications, and the Regional Development Agency Pinrang).

\section{Result and Discussion}

Ecotourism for City Branding: Perspective from Government. Neither city branding nor ecotourism is officially programmed by local government. The concept of city branding or ecotourism is not a priority for the Pinrang District government program. This finding was concluded based on interviews 
with resource persons at the Office of Tourism, Youth and Sports, Information and Communication Service, and Regional Development Agency Pinrang.

Regarding city branding, the Office of Tourism and Information and Communication Agency will still put forward the hero figure of La Sinrang as the identity and icon of the city. Bappeda does not explicitly maintain the figure, but delegates it to the relevant work unit.

"ini pahlawan jadi kalo itu icon itu barangkali hanya apanya..design nya yang barangkali.tapi La Sinrang itu akan tetap karena Lasinrang itu sudah menjadi icon Pinrang. Makanya Pinrang kan berasal dari..La Sinrang itu tidak bisa sampai dunia ini kiamat." "This is a hero, so if it's an icon, maybe it's just what the design is ... maybe, but La Sinrang will still be because La Sinrang has become an icon of Pinrang. So Pinrang isn't from ... Is that Sinrang can't get to this world of doomsday "

Saya gak tau lah kalau ada yang mau pakai-kan. Selama ini namanya kan banyak kota Sinrang, toh. Sinrang seorang pahlawan, tapi selama ini lah Sinrang sih. Selamat datang di bumi La Sinrang (I don't know if anyone wants to use it. So far, there are many Sinrang cities, after all. Sinrang is a hero, but all this time it's Sinrang. Welcome to the land of La Sinrang)

La Sinrang, according to literature, was the local hero of the Pinrang region who fought against Dutch colonialism until the end of his life (Nasruddin, 2016). The name La Sinrang is widely used as the name of a place in Pinrang, there is even the La Sinrang Park in the city center. The statue of La Sinrang also stands as an icon of the city marker. The mention of Bumi La Sinrang is pinned to Pinrang district.

The ecotourism industry in Pinrang has so far not been given priority. In the Regional Tourism Development Master Plan (2017), the first priority is given to Family Tourism in the form of developing beaches such as Ammani Beach. The development of natural tourism is mentioned as a 'special interest tourism'. This condition may be related to the reality in the field, namely infrastructure limitations and land ownership conflicts.

Mapping ecotourism potential for city branding needs to pay attention to the most basic stages of tourism, namely 4A (Etchter, 2002). Namely: (1) Attraction (2) Accessibility (3) Amenities, and (4) Ancillary. The attraction of natural tourist attractions in Pinrang, as recorded in the RIPDA document, is found in almost all sub-districts in Pinrang. The region also has a variety of rich natural attractions, including forests, mountains, waters and beaches; both natural and built. Recorded in the document are 12 beaches, 4 waterfalls, 2 mountain top areas, caves, dams and springs. However, the availability of access, facilities and institutions cannot yet be clearly identified. A case in point is Puncak Karomba. The place is known on social media and mass media. However, as it turns out, the Puncak Karomba location has not been officially opened and has no permission (Tribun Timur, January 2, 2017). Sources at the Tourism Office said that the Puncak Karomba land was still a disputed land with the private sector and Perhutani. In addition, there is no adequate access to get to this place.

Regarding opportunities and challenges, institutionally, starting in 2017 there is the Tourism Office. In addition, the Department of Information and Communication has devices such as smart city applications KemanaPinrang and control room Jendela Pinrang as a digital information center. Another opportunity is to utilize social media and maybe also be integrated into smart city devices that have been operated in Pinrang

"nah iya lomba foto kemaren kita laksanakan apalagi kan lewat di media ini media sosial. Saya kira semua potensi di Pinrang itu sudah ini Cuma barangkali belum ini.." "karena memang tidak bisa dipungkri bu sekarang orang dengan mengupload kan sudah tersebar ke luar jadi contoh kasus belum kami promosikan tapi sudah meningkat. Belum ada promisi khusus dari pemda tapi karena media sosial yang cukup (well, we did a yesterday photo contest especially through social media. "I guess all that's potential in this Pinrang Just maybe not this .. "" because it cannot deny by uploading right now people have spread out so we are promoting a case yet but it has improved. There is no special promotion from the local government but because of sufficient social media)". 
The challenge for using this smart city device is in the content. Information and Communication office said that they are as the application provider has submitted to their respective parties such as Tourism Office.

\section{Conclusion}

Mapping the potential of ecotourism as a city branding strategy from the government is the management of existing resources. The government will set the city branding policy while regulating the tourism industry so that its role will be very significant. This study is an identification of the opportunities and challenges faced by local government so that it is expected to be a reflection and also recommendations in the formulation of subsequent regional policies

Acknowledgment. This study was funded by the Ministry of Research and Universities through the Higher Education Primary Research Scheme in 2018.

\section{References}

Ady, M. M. A. (2015). Findings in Interviews on Motivation of Farmers for the Improvement of Paddy Rice Quality and the Implementation of New Methods of Paddy Rice Production in the Chiba Prefecture. 人文社会科学研究 第 31 号. Retrieved from https://core.ac.uk/download/pdf/97064981.pdf

Eli Jamilah, Suharyanti, Mirana Hanathasia (2017). "Potensi Ekowisata sebagai Upaya City Branding: suatu Study Pendahuluan di Kabupaten Pinrang." Prosiding the $1^{\text {st }}$ Communication, Culture, and Tourism Conference 2017. Buku 1. Aspikom dan FISIP Universitas Riau.

Echtner, C. M. (2002). The content of Third World tourism marketing: a 4A approach. International Journal of Tourism Research, 4(6), 413-434.

Fandeli, C. (2000). Pengertian dan konsep dasar ekowisata. Di dalam: Fandeli, C., dan Mukhlison, Editor. Pengusahaan Ekowisata. Yogyakarta: Fakultas Kehutanan UGM, Unit KSDA DIY, Pustaka Pelajar.

Nasruddin, N. (2016). Sejarah dan Budaya Lokal: dari Sulawesi sampai Bima. Makassar, IAIN Alaudin.

Tafalas, M. (2010). Dampak Pengembangan Ekowisata Terhadap Kehidupan Sosial dan Ekonomi Masyarakat Lokal (Studi Kasus Ekowisata Bahari Pulau Mansuar Kabupaten Raja Ampat).

Yananda, M. R., \& Salamah, U. (2014). Branding Tempat: Membangun Kota, Kabupaten, dan Provinsi Berbasis Identitas

Zenker, S. (2011). How to catch a city? The concept and measurement of place brands. Journal of Place Management and Development, 4(1), 40-52. 